VOLUME 2 Number 2 Page 29-36

\title{
Teachers' Feedback in Group Works of EFL Learning: Does It Influence Students' Success?
}

\author{
Absharini Kardena \\ IAIN BUKITTINGGI \\ absharinikardena@yahoo.co.id
}

\begin{abstract}
As one of suggested teaching techniques in EFL context, one of important stages in implementing group work is allocating time for testing students' comprehension. This stage is claimed to be an important stage since it aims to evaluate teaching and learning processes. Moreover, this evaluation demands any feedback order to improve the quality of teaching and learning processes and even group work activity. In other words, group work also requires such evaluation in terms of feedbacks order to get the maximum effect of this teaching technique for the students. The case found at MAN kota Solok, a state Islamic senior high school at Solok city, West Sumatera, indicated that some English teachers have not optimally offered feedback for the students in group work activity. This article, which is derived and further developed based on research conducted in 2013, aims to explore the role of teachers' feedback concerning the success of EFL learning at MAN Solok city. The research was conducted under qualitative design in which it searched out how the teachers offered feedback and how it influenced students' success in learning EFL class. The research found that the teachers offer two kinds of feedback; they were praise and critics. Besides, it was found that the feedback offered influenced students' success in learning activity. The result of this research can be used as a basic consideration for the English teachers in conducting group work activity. It is expected that the English teachers later can optimize their roles in offering feedback to the students during group work activity.
\end{abstract}

Keywords: Teachers' Feedback, Group Works, EFL Learning

\section{Introduction}

As one of the motions in communicative approach, students are demanded to be able to use the language order to acquire it. As a part of communicative approach, implementing group work takes a high degree of attention since it is claimed as one of teaching techniques that can encourage students to participate in the classroom, especially for EFL learners (Kasim, 2015). It demands the students to communicate in classroom or even in real life. As a result, the group work is suggested to be implemented.

The implementation of group work is not always about students itself, but also the teacher. None of us can judge group work as neither a business of students only nor teacher's business only. This activity involves the students and also the teacher
(Kardena, 2019). The implementation of group works involves the teacher to take part in controlling and managing its process (Smith, 2008). The teacher does not only require to plan and implement the group works, but the teacher also supposes to evaluate students' work in terms of offering feedback for their performance. In fact, the feedback is not merely about the result of the discussion or group work only, but also about the students' progress during the process of discussion on their groups. In other words, the teacher has a responsibility to evaluate every stage done by the students during the process of group work activity (Hyland, 2006).

The responsibility for evaluating students' work is not as simple as walking around the class and monitoring their work. 
However, the teacher should evaluate students' problems during the process and measure whether the students reach the goal of teaching and learning processes or not (Bloom, B \& Gardner, 2002). It is important to be evaluated since group work is a tool used to achieve the goal of teaching and learning processes. It directs the teacher to look at students' progress and their final achievement.

One of important stages in conducting group work is offering feedback on learners' performance in their group. The feedback is a way of evaluating what students do during group works activity. As stated by Klimova, feedback is an important part in learning process since it can give beneficial input both for students and teachers (Klimova, 2015). There are several advantages to offering feedback. Besides, there are also some kinds of feedback that are recommended to be applied in the classroom. In line with this, the teacher has to know how to offer feedback so it can be effective in improving students' ability.

In offering feedback, the teacher should point out some options that are related to the conditions of students, environment and culture. Nunan states "feedback helps us to become more aware of what we do and how we do it. Receiving it give us an opportunity to change and modify order to become more effective. To be helpful, feedback needs to be given in concerning and supportive way and to include both positive and negative observations" (Nunan, 1998). Besides, Black explains that the teacher has to focus on the following things in giving feedback (Black, 2008):

1. focus more on the behavior rather than the person.

2. focus more on observations rather than inference

3. focus more on descriptions rather than judgment

4. focus more on limiting the amount of information to what the receiver can use rather than the amount teacher would like to give

Moreover, Nunan explains that feedback can be classified into two; they are positive and negative feedback (Nunan, 1998). Positive feedback has two principal functions that are to let students know that they have performed correctly and to increase motivation through praise. However, negative feeedback usually consists of repeating students' responses with a raising intonation. In offering feedback, Nunan claims that a teacher should pay attention to whom gets the feedback and what kind of word of praise or correction that is used (Nunan, 1998).

In addition, Black proposes several points to consider when giving feedback (Black, 2008). They are:

\begin{tabular}{|c|c|c|}
\hline 1 & Comment on positives & $\begin{array}{l}\text { Whenever possible, try to give some (genuine) positive feedback - } \\
\text { it makes the negative easier to bear. }\end{array}$ \\
\hline 2 & Be specific and clear & $\begin{array}{l}\text { For instance, "I think that the draft you've given me needs more } \\
\text { thorough editing here, and here", rather than "Your writing is } \\
\text { really shoddy." }\end{array}$ \\
\hline 3 & Own the statement & $\begin{array}{l}\text { Use 'I' statements rather than 'you' statements, e.g. "I find your } \\
\text { description confusing" rather than "you sound confused here". }\end{array}$ \\
\hline 4 & Don't wait & $\begin{array}{l}\text { Immediate feedback is the most valuable. If this is not possible, } \\
\text { give it as soon as you can. }\end{array}$ \\
\hline 5 & Offer constructive ideas & $\begin{array}{l}\text { For instance, "If you put XXXX instead of YYYY that would read } \\
\text { better. }\end{array}$ \\
\hline
\end{tabular}

Those roles are suggested to be used by the teacher order to achieve a good result of group works activity. The teacher still has a responsibility in handling the class even though the activity is done dominantly by students.

Moreover, offering feedback to the students should also be conducted by considering students' perceptions. Burke states that the English teachers are expected to give a chance for the students to evaluate their learning success in group work (Burke, 2011). He explains that the students should be given a chance to list their contributions during group work activity and list the aspects which worked and which did not work during the activity. It aims to get students' perception about the effectiveness of group work activity. By considering those perceptions, the teachers may offer more effective feedback.

Besides, based on the research 
conducted by Wanchid, students' preferences in group work activity should also be evaluated since it may give a reflection for the teachers of more appropriate kinds of feedback offered for the students (Wanchid, 2015). Wanchid claims that students' level of ability and their preferences in using types of group work may also influence the students' success in learning English through group work (Wanchid, 2015). Thus, he suggests the English teachers to keep attention to this aspect when offering feedback to the students.

Furthermore, evaluating students' work involves the way the teacher comments students' work and any valuable critics and rewards for the students. This article is based on a research done by Kardena in 2013 in which group work was a part of the whole of the research (Kardena, 2014). Based on the preliminary research, it was known that 5 English teachers at that school applied for group work in their classroom. However, based on the preliminary observation, it seemed that the teachers did a routine activity during group work, started from planning until evaluation. Since feedback itself was one of the important keys in improving students' ability in English, this phenomenon should be investigated well order to know how the teachers offer feedback to the students and how it influences students' success in learning English as a foreign language. It was expected that this research would give contribution to the English education field study and also stakeholders and practitioners to take any decisions for English language study in Indonesia. Hence, this article explains the way the English teachers at MAN Solok city offered feedback on students' work as a process of evaluation. Besides, this article also explores the influence of students' feedback on the success of EFL learners at MAN Solok city. Moreover, this research aims to find out how the feedback offered by the English teachers in group work activity influences the students' success in EFL class.

\section{Method}

This research practically used a qualitative approach. The study was conducted at MAN Solok city. There are 5 English teachers in MAN Solok city who were being the participants of the research. In this case, the participants were all the English teachers since all of them used group works. Because this research investigated the feedback given during group work activity, those 5 English teachers were involved as the participants of the research. The research was conducted by using observation and interview. The teachers were observed during the implementation of group work, especially when they offered feedback to the students, whether it was in the middle or the end of the group work. The observation was conducted without taking a video order to avoid any bias during the observation. Hence, the researcher was non-participant observer who took a note during the observation. Moreover, the teachers were interviewed order to get deep data behind any actions taken by the teachers during offering feedback to the students. The data were analyzed scientifically by adapting the technique of data analysis proposed by Patton. The steps in analyzing the data are explained as follow (Patton, 1990):

1. Epoche.

In this step, the researcher differentiated between participants' point of view, assumption or prejudice. Other words, the researcher should be able to clarify any personal bias from the data collected.

2. Phenomenological reduction

In this stage, irrelevant data should be put out. Moreover, the researcher got the real facts of the data.

3. In grouping the real data, here are the steps followed:

a. the researcher decided any phrases or statements that show the facts of the phenomenon.

b. the researcher interpreted the meaning of the phrases or statements.

c. the researcher explained the participants' opinion about the statements.

d. the researcher looked over these meanings for what the essential opinion of the participants.

e. the researcher offered a tentative statement, or definition, of the phenomenon in terms of the essential recurring features identified.

4. The textual portrayal of each theme The researcher described experience of the participants.

5. Development of structural synthesis 
6. The researcher described the deeper meaning of participants' experiences; the true meaning contains in those experiences.

\section{Findings and Discussion}

Data of the research were analyzed by using observation and interview. The data dealt with the way the teachers offered feedback to the students and its impact on students' success in EFL class. In a more detailed explanation, the way to offer feedback is indicated by 2 main points; they are giving rewards, and giving critics.

Giving rewards is a part of offering feedback. In general, rewards can be stated as positive feedback since it can encourage students to work better through appreciating their work (Nunan, 1998). In this case, the data of observation tell that the teachers often gave positive feedbacks through giving praise and motivating students to work together in their group. However, there was some ineffectiveness when they offered the positive feedback for the students.

The first point is the praise given was not specific and did not offer constructive ideas for the students. The ways of the teacher in offering feedback were only by saying "good, excellent, etc" for the whole activities done by the students. The teachers did not inform the students about the positive points that they did. In fact, the positive points should be informed since it can be a lesson for other students who have not done the tasks well. In this case, the teachers walked around the groups and looked at students' works and said "good". This comment generalized students' work. Consequently, the students did not know whether the praise "good" was pointed to their works as a team or the progress of their task or even just a motivation to keep spirit in accomplishing the task.

The second point is taken from the data of observation. It was found that at the end of the lesson, the teachers also did not give any comment for the group which performed in front of the class. It can be academically argued that the teachers did not appreciate what the students have done. The teachers did not show any reflections for the groups as a whole or for each member of the groups. Consequently, the students cannot assume how good their task was. It would be more valuable for the students if they were appreciated for their effort. However, the general praise given by the teachers was only to say "good" or "very good."

Accordingly, the explanation above can be analyzed from students' points of view. Logically, great praise should lead students to work better and get great achievement. However, the data of observation proved that the students were not motivated to learn better since the praise given was not stated well. It indirectly impacted on students' achievement in which a brave student took handle in presenting the materials and the others just kept listening to him/ her. Consequently, the students who were lack of competence did not improve their ability. On the other hand, the brave students would be better. The impact of non-praise phenomenon leads the students to think that they were not evaluated individually, but as a group evaluation. It supported by the interview as stated below:

Transcription 1:

R: 'jadi terkait dengan umpan balik yang ibuk lakukan, apa saja yang ibuk lakukan atau sampaikan pada anakanak sehingga mereka bisa semangat belajar?' ('in case of feedback you offered, what do you do or say to motivate your students to work in group?')

T2: 'anak-anak ini kan memang harus kita motivasi kan, biar semangat belajarnya. Malah kadang kita katakan saja dulu kalau hasil kerhanya sudah bagus, padahal ya gitulah, ini salah itu salah. Tapi kita biarkan saja lah dulu selagi mereka masih mau belajar kan' ('the students must be motivated to learn. Sometimes we just said that their works are good although they are not. However, we let it as far as they are eager to learn')

$\mathrm{R}$ : 'itu diberikan menyeluruh atau pada individu yang memang bekerja bagus dikelompoknya bu?' ('did you say it to all the students or only to particular students who work well?')

T2: 'ya pada semuanya. Kalau tidak, ya yang tidak bisa tambah tidak semangat' ('to the whole of students, so that the students who are not good will not be motivated anymore')

$\mathrm{R}$ : 'menurut ibu anak-anak tu sudah meningkatkan ndak bu kemampuannya setelah dimotivasi?' '('do you think they improve themselves after you motivate 
them, on the next meeting?')

T.2: 'sebenanrnya agak sulit ya untuk tau pasti hasilnya. Tapi ya dicoba untuk mengamatinya dari hasil ujiannya saja.' ('a yeah it's difficult for us to get how the result is, how the result is. But we have to see them, we have to see them on their test; the result of the test that we have done.')

The transcription above tells that the teachers appreciated students' work by giving general feedback and it was given to almost all the groups. In other words, it can be stated that the teachers' feedback in group work activity did not give a positive impact on students' success in EFL class.

To simplify the data above, figure 1 illustrates the positive feedback and its influence on students' achievement.

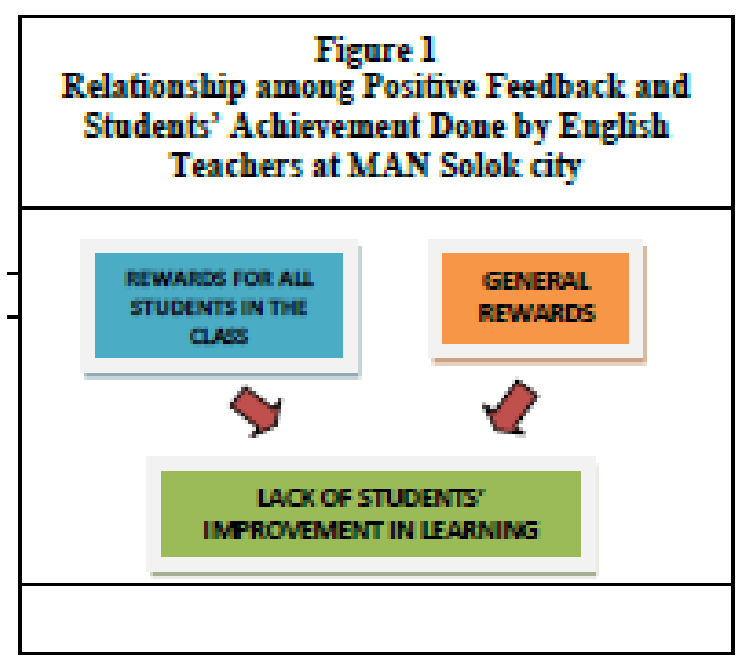

Figures 1 tells that rewards are given to the whole of class and the general statements as the rewards do not give a specific contribution to students' achievement. It leads to lack of students' progress in achieving goals of teaching and learning processes. The general rewards lead the students to think that they do not do something special and better than other groups. The students are not motivated to learn. They might question the reason to do group work and its advantages for their learning success. It is supported by Black who states that, in offering feedback, the teacher should state specific and clear comments so that the students may get the idea in which part they are categorized good or poor (Black, 2008). He adds that the students should be appreciated for anything they did even the small thing. Shortly, it can be stated the teachers did not give correct praise and rewards that caused lack of students' motivation to work on their groups. Thus, there's little improvement got by the students in learning EFL through group work activity.

By considering this phenomenon, it can be stated that the teachers did not optimally offer feedback to the students. It should be noticed that offering feedback requires not only knowledge of feedback itself, but also require (Hattie, J \& Timperley, 2007). It was strengthened by Baranek who claimed that a teacher has to be trained order to give a beneficial feedback which can increase students' intrinsic motivation (Baranek, 1996). In a deeper explanation, he stated that whenever the teacher gives praises for the students, the main goal should be on building students' intrinsic motivation and not only on a small scale of giving rewards. Furthermore, he argued that offering reward and/ or praises requires such skill so that it can achieve the appropriate goal. It can be simplified that whenever the teacher gives praises or rewards as a positive feedback, this feedback should contain not only a sign of students' good job but also involve an effort to increase students' motivation in learning.

The second indicator in offering feedback was giving critics at the end of the lesson. Based on the data of the research, it was found that all teachers criticized students' works after the groups performed in front of the class. Some teachers criticized the general points that often being mistakes or errors. One of the critics given related to the grammar used by the students in their writing. The teachers lead students' attention to mistake and errors that commonly appear related to the use of tenses (simple resent and present perfect tense). Besides, one teacher also criticized students' writing based on the arrangement of ideas. In addition, the teacher also criticized students' work specifically based on group mistakes and not individually. It is supported by the interview with the teacher as stated below: Transcription 2:

R: '... untuk koreksi yang ibuk berikan, kapan ibu berikan dan cara...' ('when do you give any corrections for the students?')

T.3:' 'oh koreksi bersifat masal jadi saya ga' mau nunjuk yang eee... eee... misalnya yang ini kerjaan kelompok ini salah, ga'. Jadi secara global gitu di akhir pelajaran. Jadi mereka itu kalau salah itu mereka ga' takut, 
mereka ga' merasa minder. Jadi, nah kesalahan yang ibuk liat tadi eee... ini 1, 2, 3, dan seterusnya. Ditulis dipapan tulis, gitu kan. Tapi saya ga' sebutkan ini kesalahan kelompok ini, ini kesalahan si B. ga' pernah begitu. Jadi biarlah mereka yang tau mereka yang salah. Biasanya mereka tau itu mereka yang salah, Cuma kita kalau kita tau si A yang salah kita jangan memandang dia disaat kita mengoreksi itu gitu. Jadi dia ga merasa gitu kan.' ('corrections are given for students as a whole, not individual or group. In other words, it is globally at the end of the meeting. The students will be not afraid to make mistake. I will say these are the mistakes you make, 1 , 2 , 3, etc... I write it on the whiteboard. However, I don't mention whose mistakes those are. Let them notice it by themselves. Commonly, they know that the mistake made by themselves. I also did not look at the students who made mistake when I explain or mention those mistakes so that they were not embraced.')

The transcription above can be simplified into the table as follow:

\section{Table 1}

Teachers' activities in offering negative feedback

\begin{tabular}{|c|c|c|}
\hline No & Teachers' activity & Notes \\
\hline 1 & $\begin{array}{l}\text { Feedbacks are given for all } \\
\text { members of the groups }\end{array}$ & Not individual feedback \\
\hline 2 & $\begin{array}{l}\text { Feedbacks are given at the } \\
\text { end of the meeting }\end{array}$ & $\begin{array}{l}\text { No feedback during the } \\
\text { process of implementing } \\
\text { group work }\end{array}$ \\
\hline 3 & $\begin{array}{l}\text { Feedbacks are written in } \\
\text { whiteboard }\end{array}$ & $\begin{array}{l}\text { Teachers' write it in a } \\
\text { list of points }\end{array}$ \\
\hline 4 & No constructive ideas & $\begin{array}{l}\text { Teachers focused on } \\
\text { pointing students' } \\
\text { mistakes and lack of } \\
\text { correction }\end{array}$ \\
\hline
\end{tabular}

Table 1 tells that the teacher considered students' motivation to learn. The teacher stated that the correction was given for all students (not individually) order to avoid any negative impact on students' motivation. In other words, the teachers avoided any actions that can make the learners ashamed of making mistakes. Criticizing the materials is a good way to avoid the individual mistakes (Hart, 2017). Besides, the teachers also tried to judge the students' work as a group. Consequently, any mistakes and errors made would not be referred to as particular students only; it can be a lesson for all students. It is relevant to theory stated by Black (2008) that the feedback given to the students should make students being more aware of what they do and how they do it.

However, based on the data above, it can be academically stated that the teachers do not give any constructive ideas related to students' final result. When the teacher state any mistake and errors, the teachers are demanded to give any correction and constructive ideas that can lead students to the correct one. It is highly needed when students' mistakes are related to the arrangement of ideas. In fact, the teachers only stated that the ideas were not cohesive and the students cannot elaborate on the ideas. However, in this case, the teachers did not offer any solution or even any options for students' writing. As explained by Black, the teachers are also suggested to give any constructive ideas as a solution to the problem faced by students (Black, 2008). Based on the analysis above, it can be argued that the teacher still needs to be trained and informed on how to offer feedback well for the students. Therefore, the feedback given by the teachers in form of critics did not give significant impact on students' learning achievement. Simply, it can be stated that students' success in EFL class is influenced by the way the teachers give critics as its feedback.

The way the teachers offered feedback as previously explained is related to students' achievement in acquiring English. The way the teachers give praise and critics for students automatically influence students' motivation and their achievement to work in groups. Whenever the teacher cannot motivate students effectively to work well by giving such constructive ideas, the students do not accomplish the task in right procedures. In fact, the teachers did not give specific comments or critics so that the students did not know their mistakes or errors. On the other hand, the teacher gave the comments, any critics, or praise in general way. Culturally, the way the teachers give feedback is not a mistake. By considering Minangkabau culture, in which the teachers and the students interact and live, offering ideas or suggestions should be communicated indirectly. Giving critics in indirect ways is the most polite way for 
Minangkabau people. The critics are not stated directly and it is also not pointed to particular person. However, for academic purpose, this way cannot give any constructive ideas to the students. The students cannot improve their ability in English, such as in tenses, word order, etc, as they do not get individual feedback for their effort. In other words, the way the teachers give feedback directly influences students' achievement. It is not relevant to theory stated by Black that the teacher should give a specific and constructive idea so that it may affect students' improvement later (Black, 2008). Besides, she also said that the teacher is suggested to give positive comments before offering any critics to the students.

\section{Conclusion}

Offering feedback for students' work in groups is a part of implementing group works. On this point, this part has an important influence on students' success in EFL learning. The feedback offered should be in forms of positive by giving rewards and praises and negative by giving critics. The teachers should be aware of students' motivation and their progress in learning. Based on this research, it can be stated that general critics for whole of students are not academically effective although culturally it is categorized polite statement. Any critics given should be followed by any constructive ideas so that the learners can learn based on their mistakes. One thing that is important for the teacher is to comprehend that giving feedback is not meant to judge the students. However, it is aimed to help the learners to be better in achieving the goal of teaching and learning processes.

Based on the argument above, the teachers are suggested to look at students' work during the process of group works and help them by giving any constructive ideas. Since feedback is necessary to improve students' achievement, the teachers are also expected to allow others to notice any mistakes made by some students so that it can be a lesson for all the students.

\section{References}

Baranek, L. (1996). The effect of rewards and motivation on students' achievement.

Black, K. (2008). Giving and Receiving Feedback.
Bloom, B \& Gardner, H. (2002). Group works. Retrieved from www.edsw.usyd.edu.au.

Burke, A. (2011). How To Use Groups Effectivley. The Journal of Effective Teaching, 11(2), 87-95. Retrieved from https://uncw.edu/jet/articles/vol11_2/ burke.pdf

Hart, L. A. (2017). The impacts of rewards on the effectiveness of performance feedback in improving writing production in elementary school students. University of Tennessee.

Hattie, J \& Timperley, H. (2007). The power of feedback. Review of Educational Research, 77(1), 81112.

Hyland, K. (2006). English for Academic Purposes. An Advanced Resource Book. London: Routledge.

Kardena, A. (2014). PROBLEMATIC SIDES IN IMPLEMENTING LEARNER INSTRUCTION PARADIGM IN ENGLISH CLASSROOM. Retrieved from http://ejournal.unp.ac.id/index.php/ko mposisi

Kardena, A. (2019). Teachers' Management Planning and Implementing for the Success of EFL Learning (Vol. 7).

Kasim, U. (2015). Implementation of group work in the classroom. Lingua, 12(1), 97-106.

Klimova, B. (2015). The role of feedback in EFL classroom. Procedia-Social and Behavior Sciences, 199(1), 172177.

Nunan, D. (1998). Language Teaching Methodology. Edinburgh: Longman.

Patton, Q. (1990). Qualitative Evaluation and Research Methods. London: Sage Publication ltd.

Smith, M. (2008). What is group works? Retrieved from www.infed.org/groupwork/

Wanchid, R. (2015). Different Sequences of Feedback Types: Effectiveness, 
Attitudes, and Preferences. PASAA: Journal of Language Teaching and Learning in Thailand, 50(December), 31-64.

Retrieved

from http://search.ebscohost.com/login.asp $\mathrm{x}$ ?direct $=$ true $\& \mathrm{db}=$ eric $\& \mathrm{AN}=\mathrm{EJ} 1088$ $304 \&$ site $=$ ehost-live 